\title{
RENATA ORLOWSKA
}

\section{PIOTR TOMASZ BEDNAREK}

SLAWOMIR BANY

Instytut Hodowli i Aklimatyzacji Roślin — Państwowy Instytut Badawczy, Radzików

Kierownik Tematu: dr inż. Renata Orłowska Instytut Hodowli i Aklimatyzacji Roślin — Państwowy Instytut

Badawczy, Radzików, 05-870 Błonie, Zakład Biochemii i Fizjologii Roślin, tel. 22 7334538,

e-mail: r.orlowska@ihar.edu.pl

Prace zostały wykonane $w$ ramach badań podstawowych na rzecz postęp biologicznego $w$ produkcji roślinnej na podstawie decyzji Ministra Rolnictwa i Rozwoju Wsi nr HOR.hn.802.19.2018, Zadanie 89.

\section{Molekularna charakterystyka wpływu elementów mobilnych na zmienność genetyczną w zbożowych kulturach in vitro}

\section{Molecular characterization of the impact of transposable elements on genetic variation in cereals tissue cultures}

Słowa kluczowe: jęczmień, kultury tkankowe, MSTD, retrotranspozony

W roku sprawozdawczym 2018 zaplanowano do wykonania cztery tematy badawcze z następującymi celami:

- uzyskanie genomowego DNA z regenerantów jęczmienia do analiz technikami RPHPLC, MSTD,

- oszacowanie poziomu globalnej metylacji DNA dla 80 regenerantów jęczmienia przy użyciu techniki RP-HPLC (Reversed-Phase High-Performance Liquid Chromatography),

— wykonanie analiz MSTD na DNA regenerantów jęczmienia - uzyskanie autoradiogramów,

- uzyskanie roślin będących generatywnym potomstwem regenerantów jęczmienia.

Analizy molekularne obejmowały ekstrakcję genomowego DNA z regenerantów jęczmienia (genotyp 2dh/8) uzyskanych na drodze androgenezy w kulturach pylnikowych. Wyziolowany genomowy DNA rozdzielono w $1,4 \%$ żelach agarozowych 
w celu sprawdzenia jego integralności. Ilość DNA oszacowano spektrofotometrycznie. Uzyskano DNA w odpowiedniej ilości i jakości do dalszych analiz.

Określono poziom globalnej metylacji DNA u regenerantów jęczmienia (80 roślin) uzyskanych w kulturach pylnikowych z 4 roślin donorowych (D). Analiza całkowitej metylacji cytydyny $(5 \mathrm{mdC})$ genomowego DNA wykonana metodą RP-HPLC wykazała, że średnio $21,31 \%( \pm 0,41)$ cytydyny uległo metylacji. Dla poszczególnych zestawów regenerantów wyprowadzonych z 4 różnych roślin donorowych uzyskano odpowiednio: JRP72-21,50\%, JRP68-21,30\%, JRP69-21,22\% i JRP70-20,15\%. Wykazano istotne różnice $(\mathrm{F}=133,274, \mathrm{p}=0,0001)$ między poszczególnymi zestawami regenerantów a roślinami donorowymi uzyskanymi w ubiegłym roku sprawozdawczym (Sprawozdanie PBwPR 89_2016).

Wykonano rozdziały metAFLP dla 80 regenerantów jęczmienia, oraz dla odpowiadających im roślin donorowych (4 rośliny). Rozdziały wykonano w dwóch układach enzymów restrykcyjnych - Acc65I/MseI i KpnI/MseI. Podjęte prace pozwoliły uzyskać czytelne elektroforegramy. Uzyskane obrazy w zależności od zastosowanych starterów w reakcji PCR różniły się wizualnie liczebnością fragmentów DNA. Zliczanie prążków DNA i tworzenie matryc zerojedynkowych będzie realizowane w przyszłym roku badawczym.

Regeneranty jęczmienia, pozyskane na drodze androgenezy były źródłem ziarniaków do uzyskania generatywnego potomstwa. W temacie zaplanowano uzyskanie około 90 roślin potomnych $\mathrm{z}$ regenerantów uzyskanych na drodze androgenezy. Aby otrzymać zaplanowane ilości roślin będących generatywnym potomstwem regenerantów wysiano ok. $10 \%$ więcej nasion, niż oczekiwane liczebności roślin potomnych. Uzyskano w sumie 90 roślin z czterech różnych regenerantów.

\section{PODSUMOWANIE}

1. Ekstrakcja DNA skutkowała odpowiednimi preparatami DNA do dalszych analiz.

2. Wykonana $\mathrm{w}$ temacie badawczym analiza RP-HPLC określiła poziom globalnej metylacji DNA dla 80 regenerantów jęczmienia. Obserwowano zróżnicowanie w poziomie globalnej metylacji DNA między zestawami regenerantów pochodzącymi $\mathrm{z}$ różnych regenerantów.

3. Uzyskano stabilne profile prążków DNA techniką MSTD do dalszych prac.

4. Uzyskano reprezentatywną liczbę roślin będących generatywnym potomstwem regenerantów pozyskanych w poprzednim roku badań. 